
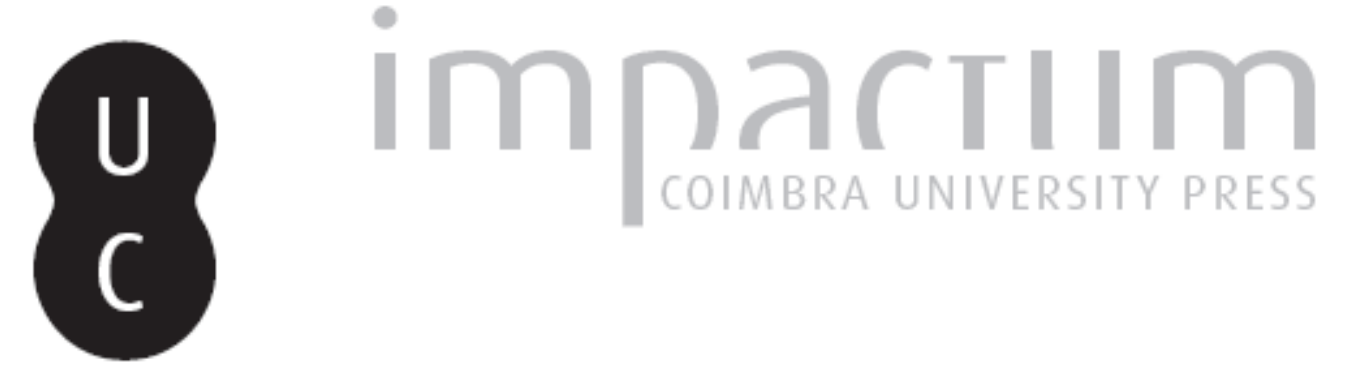

\title{
[Recensão a] POLITIS, V. (2015). THE STRUCTURE OF ENQUIRY IN PLATO'S EARLY DIALOGUES
}
Autor(es):
Sabrier, Pauline
Publicado por: Annablume Clássica; Imprensa da Universidade de Coimbra
URL persistente:
URI:http://hdl.handle.net/10316.2/38308
DOI:
DOI:http://dx.doi.org/10.14195/1984-249X_16_13
Accessed : $\quad$ 26-Apr-2023 11:31:38

A navegação consulta e descarregamento dos títulos inseridos nas Bibliotecas Digitais UC Digitalis, UC Pombalina e UC Impactum, pressupõem a aceitação plena e sem reservas dos Termos e Condições de Uso destas Bibliotecas Digitais, disponíveis em https://digitalis.uc.pt/pt-pt/termos.

Conforme exposto nos referidos Termos e Condições de Uso, o descarregamento de títulos de acesso restrito requer uma licença válida de autorização devendo o utilizador aceder ao(s) documento(s) a partir de um endereço de IP da instituição detentora da supramencionada licença.

Ao utilizador é apenas permitido o descarregamento para uso pessoal, pelo que o emprego do(s) título(s) descarregado(s) para outro fim, designadamente comercial, carece de autorização do respetivo autor ou editor da obra.

Na medida em que todas as obras da UC Digitalis se encontram protegidas pelo Código do Direito de Autor e Direitos Conexos e demais legislação aplicável, toda a cópia, parcial ou total, deste documento, nos casos em que é legalmente admitida, deverá conter ou fazer-se acompanhar por este aviso.

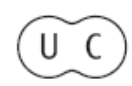


16

jan/apr

2016

issn 2179-4960

e-issn 1984-249X

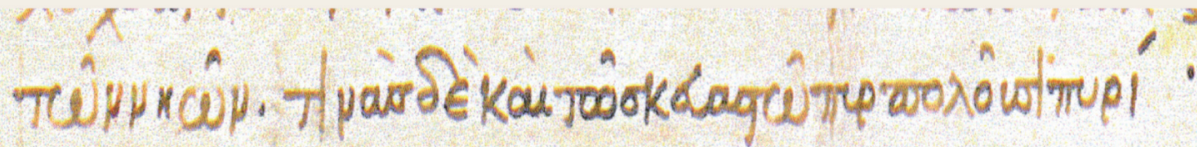

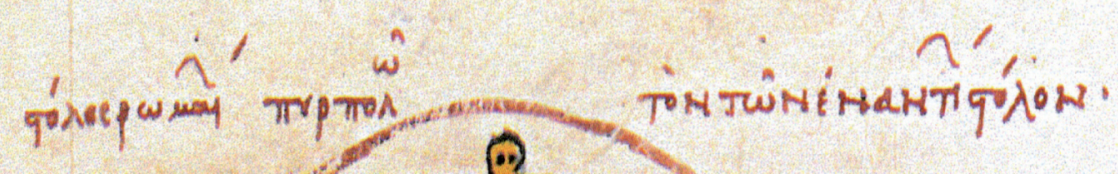
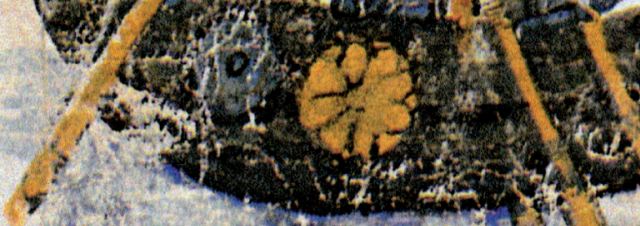

,

.
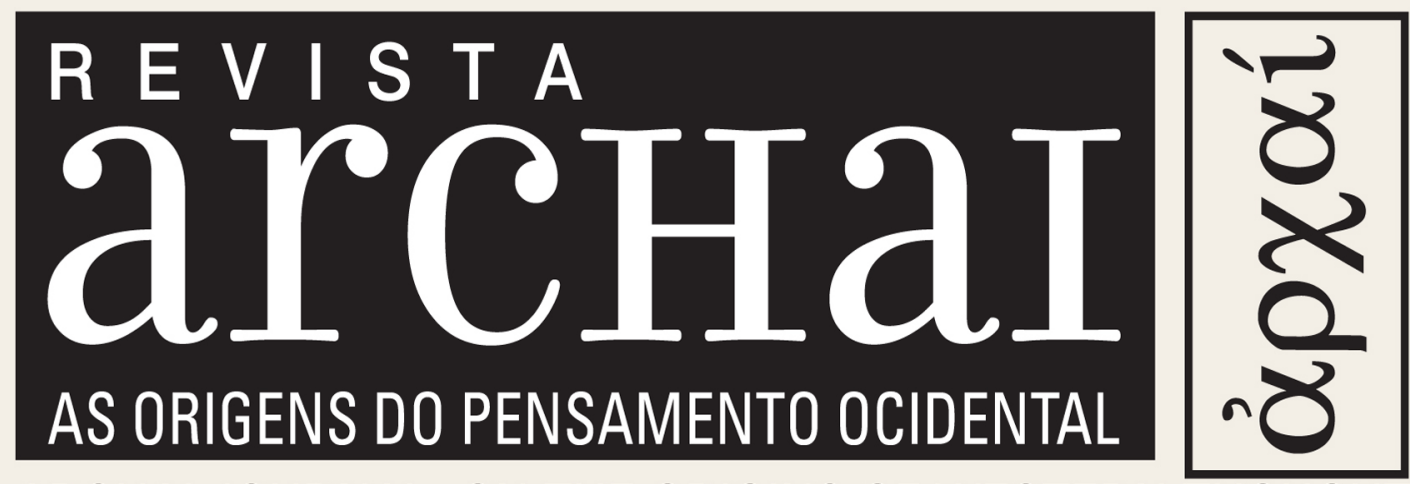

ARCHAI JOURNAL: ON THE ORIGINS OF WESTERN THOUGHT

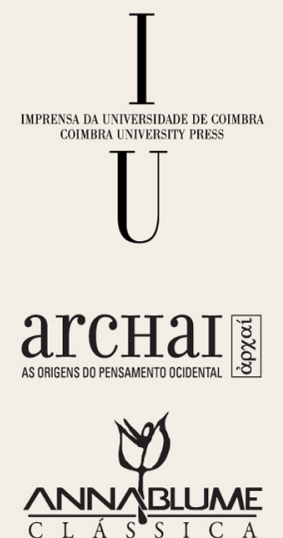


Pauline Sabrier

Trinity College Dublin (Ireland)

pauline.sabrier@orange.fr

\section{POLITIS, V. (2015). THE}

\section{STRUCTURE OF ENQUIRY IN}

\section{PLATO'S EARLY DIALOGUES.}

\section{CAMBRIDGE, CAMBRIDGE UNIVERSITY PRESS.}

SABRIER, P. (2016). Resenha: Politis, V. (2015). The Structure of Enquiry in Plato's Early Dialogues. Cambridge, Cambridge University Press.

Archai, n. 16, jan.-apr., p. 219-221

DOI: http://dx.doi.org/10.14195/1984-249X_16_13

Vasilis Politis' book provides a new insight into Plato's early dialogues. The purpose of the book is to defend an 'aporia-based account' of Plato's early dialogues against the common 'definition-based account'. Traditionally, the early dialogues are read as 'definitional' in the sense that the $t i$ esti question is seen as the central question motivating the inquiry, and as 'aporetic' in the sense that they generally end in the failure of Socrates and his interlocutors to answer the ti esti question. Usually, the failure is attributed to the incapacity of Socrates' interlocutor to provide an answer to the ti esti question which meets Socrates' requirements, which are that the question should be answered by giving a unitary, general and explanatory definition of $\Phi$ and not by pointing at an example. One problem with this

\section{arcHaI愿}

n. 16, jan.-apr. 2016 


\section{arcHaI \\ AS ORIGENS DO PENSAMENT OCIDENTL}

n. 16, jan.-apr. 2016

SABRIER, P., Politis, V. (2015). The Structure of Enquiry in Plato's Early Dialogues. Cambridge, Cambridge University Press

p. 219-221 view is that the reason for these requirements is either left unexplained, or it is explained dogmatically, by putting forward Plato's own theory of knowledge, or it leaves room for suspicions of scepticism, the failure of the dialogue pointing to the impossibility of knowledge. Starting from the difficulties raised by the traditional view, Politis develops a radically different approach in which the ti esti question is not any more the central question of the dialogue. Instead, he shows that the inquiry is motivated and structured by questions of the form 'whether or not $\Phi$ is $\Psi$ ' which turn into aporiai when one or more of the interlocutors, after having argued on both sides of the question, face a conflict of reasons and it appears to them that there are equally good reasons on both sides. Based on textual evidence, Politis' central claim is that it is in order to find a way out of the aporia that the ti esti question, understood as the demand for a standard for a thing's being $\Phi$, is raised in these dialogues, and furthermore, that it is in order to unlock the particular case of 'radical aporiai', that is aporiai which render every example-and-exemplar questionable, that Socrates requires a unitary, general and explanatory definition. It is thus the understanding of the early dialogues as being primarily aporia-based dialogues which provides the key to the ti esti question.

The book is divided into two parts. Part I is dedicated to the criticism of the 'definition based-account'. Politis' point is to show, against this view, that the ti esti question stands in need for justification, and consequently, that the ti esti question cannot alone be the crux of the dialogue. Three elements are put forward: first, the place of the ti esti question in the inquiry, which, Politis shows, is raised at different places depending on the dialogue, including at the very end; secondly, Socrates' requirement to answer the ti esti question by giving a unitary, general and explanatory definition, and not by pointing at an example; and, thirdly, the supposed benefits of answering the ti esti question, which explains why it is seen as an indispensable step by Socrates and is pursued relentlessly. The second point has, in particular, crystallised the attention of critics. On the whole, those who have recognised the need for justification of the requirements for definitions have either argued against Plato that such a justification is missing (Peter Geach, famously) or that the justification is to be found in Plato's theory of knowledge. Politis argues for a third way namely, that Plato's justification is indeed to be found in the dialogues - this is the whole point of Part II - but that it is not to be found in his theory of knowledge. Large sections of Part I are dedicated to the latter issue, which certainly constitutes one of the main strengths of the book.

Part II is the constructive part of the book, where Politis argues that the raising and the pursuing of the ti esti question is in fact motivated by the emergence of an aporia within the dialogue. The first step consists in establishing that the ti esti question is always preceded, or raised together with, one or many questions of the form 'whether or not $\Phi$ is $\Psi$ '. This claim is based on the study of a large range of dialogues - Charmenides, Euthyphro, Republic I, Gorgias, Hippias Major, Laches, Protagoras, Meno, Lysis - which are brought under close examination. In a second step, 
Politis shows how some of these whether-or-not questions articulate an aporia, that is a conflict of reasons such that there appears to one and the same person to be genuinely good reasons on both sides of the whetheror-not question, and how then it is in order to find a way out of the aporia that a ti esti question, that is the question for a standard of a thing's being $\Phi$, is raised. Again, the argument is carried through the careful study of four dialogues - Euthyphro, Charmides, Protagoras, Meno. Finally, Politis develops the notion of 'radical aporia' to explain that some aporiai are such that they render questionable every example-and-exemplars of a thing's being $\Phi$, and that this is the reason why Socrates, in this precise situation, requires that the ti esti question must be answered not by pointing at an example but by giving a unitary, general and explanatory definition of $\Phi$.

Politis' book is undeniably of great value for the study of Plato's early dialogues. Not only does it challenge the traditional view on the ti esti question, but it completely renews the role of aporiai in these dialogues. If aporiai still refer to a state of puzzlement, they are more fundamentally a decisive moment in an inquiry and they show that a further step is required in order to pursue the original issue. Given that whether-or-not questions naturally provide the ground for the emergence of aporiai, and given that, as Politis has shown, Plato in these dialogues takes the raising of whether-or-not questions as his starting-point, one could say in that sense that Plato is an aporetic thinker. However, this should not be interpreted in any way as implying that Plato is a sceptic. Politis devotes a chapter in Part II to refute this claim, which has being considered by Julia Annas and more recently defended by Michael Forster. Politis argues against this view that if there is indeed a sceptical dimension in the method of aporia-based inquiries, the raising of the ti esti question shows on the contrary that the moment of the aporia is meant to be overcome. The ability of Politis to tackle all these different aspects of the topic is another major asset of this book. For instance, the apparent paradox of Socrates' ignorance, who on the one side denies that he possesses any knowledge but on the other side defends some strong positions, a paradox which becomes acute in the Gorgias for instance, is also addressed. Finally, the significance of the book goes beyond the early dialogues. As the author himself puts it, the careful study of the raising of the ti esti question brings us to the roots of Plato's essentialism', and as a result, it is likely that such an important change in the understanding of the role of the ti esti question in these dialogues will have consequences for our understanding of the theory of forms. In particular, the fact that only radical aporiai require answering the $t i$ esti question with a unitary, general and explanatory definition could have implications for the question of whether there is a form for each and every thing. But this point goes well beyond the scope of the book, and accordingly, Politis does not deal with it. Nonetheless, this is another element which makes this book so valuable for any student of Plato and, I think, many students of philosophical method and enquiry.

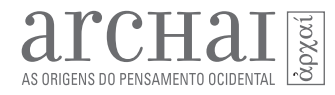

n. 16, jan.-apr. 2016

SABRIER, P., Politis, V. (2015). The Structure of Enquiry in Plato's Early Dialogues. Cambridge, Cambridge University Press

p. 219-221 